\title{
PO TRIANON. ZMIANY W FUNKCJONOWANIU PARLAMENTU WEGGIERSKIEGO
}

\author{
AFTER TRIANON. CHANGES IN THE FUNCTIONING \\ OF THE HUNGARIAN PARLIAMENT
}

On 16 November 1918 the bicameral National Assembly terminated its activity, but the new legislative body was not able to take up its role until the beginning of 1920. The two-year functioning of the unicameral National Assembly was marked by certain duplicity. On the one hand, a certain democratization process was taking place, apparent as regards strengthening and expanding parliamentary functions. On the other hand, as a result of unstable party structures and political rivalry dominating the activity of the National Assembly, the discussed institution was incapable of creating a stable system of governance, which left considerable leeway for Prime Minister István Bethlen.

Słowa kluczowe: demokracja, kontrrewolucja, skuteczność, izba poselska, rząd, partia rządząca, Zgromadzenie Narodowe, ustawodawstwo, prawo wyborcze, debata

Key words: democracy, counterrevolution, efficiency, Chamber of Deputies, government, ruling party, National Assembly, legislation, electoral law, debate

* Prof. Levente Püski, wykładowca akademicki, Debreceni Egyetem, puslev@freemail.hu, https://orcid.org/0000-0002-3879-8893

\section{PIERWSZE ZMIANY W ZGROMADZENIU NARODOWYM}

Ta Węgrzech - po zawarciu ugody z Austrią w 1867 r. - powstał nowy system sprawowania władzy pod wieloma względami o charakterze liberalnym, a częścią tego systemu było dwuizbowe Zgromadzenie Narodowe. Rola przegranego w wojnie oraz wewnętrzne napięcie społeczne i polityczne doprowadziły do rewolucyjnych przemian, a nowa ekipa rządząca, uzyskująca władzę po zwycięstwie rewolucji 31 października 1918 r., nie pragnęła skorzystać z usług dotychczasowego ustawodawstwa. Dnia 16 listopada izba poselska ogłosiła samorozwiązanie, a izba wyższa tego samego dnia zakończyła obrady. Chociaż na początku 1919 r. nastąpiła pewna próba utworzenia nowego parlamentu, to jednak realizacja tego zamiaru ostatecznie przepadła 21 marca wraz z ogłoszeniem Republik Rad. Dyktatura pragnąca wzorować się na radzieckim ustawodawstwie powołała organ ustawodawczy pod nazwą Krajowe Zgromadzenie Rad, ale nie posiadał on żadnej legitymizacji państwa.

Po upadku Republiki Rad przejściowo nastąpił całkowity rozpad władzy w państwie, a większość kraju została zajęta przez obce siły militarne — przede wszystkim rumuńskie. Wyjściem z tej katastrofalnej sytuacji była stopniowa likwidacja okupacji oraz równolegle z nią ma stworzenie ustroju państwa zdolnego do samodzielnego funkcjonowania i mającego międzynarodowe uznanie. Pod przywództwem Károlya Huszára (polityka chrześcijańsko-socjalistycznego) 24 listopada 1919 r. powstał 
pierwszy rząd, który miał międzynarodową legitymizację. Następnym etapem procesu stabilizacyjnego było powołanie nowego organu ustawodawczego, stopniowe wycofanie wojsk rumuńskich przeprowadzone równolegle z powstaniem rządu Huszára. Sposób przeprowadzenia wyborów regulowało kilka rozporządzeń rządu, ale najważniejszym aktem prawnym okazało się rozporządzenie (nr 5985/1919) wydane 13 listopada $1919 \mathrm{r}$. jeszcze przez ówczesnego premiera Istvána Friedricha, które określało podstawy prawa wyborczego, m.in. ustanowiono, że w przypadku spełnienia pewnych warunków, każdy mężczyzna i każda kobieta, którzy ukończyli 24 lata, mają prawo do głosowania, dzięki czemu blisko 40\% ludności uzyskało prawo do oddania głosu. Głosowanie miało być tajne i obowiązkowe, wprowadzono też system okręgów indywidualnych, istniejący przed $1918 \mathrm{r}^{1}$

W ostatnich miesiącach $1919 \mathrm{r}$. rozpoczęły się poważne przetasowania w polityce partyjnej. Istniejąca od początku stulecia dominująca linia podziału w prawie publicznym wraz z upadkiem monarchii austro-węgierskiej straciła sens, jednocześnie przeważająca większość starych organizacji nie przeorganizowała się. W efekcie ich miejsce zaczęły przejmować partie masowe. Co prawda z początku pojawiło się wielu samozwańczych polityków oraz namnożyły się partie o przeróżnych nazwach, posiadające różne zaplecza subkulturowe. Jednak ta sytuacja, która wyglądała na dość zagmatwaną, na początku $1920 \mathrm{r}$. — przynajmniej od strony formalnej — znacznie się uprościła. W październiku 1919 r., w wyniku zjednoczenia ugrupowań z przeróżnymi nazwami chrześcijańskimi, powstała Partia Chrześcijańskiej Jedności Narodowej. Krajowa Niezależna Partia Rolników aspirująca do wspierania ludności chłopskiej i agrarnej 29 listopada 1919 r. zjednoczyła się ze Zjednoczoną Partią Posiadaczy Rolnych i Rolników, przybierając nazwę Niezależnej Partii Drobnych Posiadaczy Rolnych i Rolników². Oprócz tych partii do walki wyborczej włączyło się wiele innych organizacji, jednak pośród nich ważne znaczenie miała jedynie Węgierska Partia Socjaldemokratyczna. Socjaldemokraci z początku szykowali się do wielkiej bitwy, jednak w połowie stycznia kierownictwo partii - czując, że ich kampania jest mocno ograniczana przez lokalne organy cywilne i wojskowe, oraz ufając, że w przyszłości okoliczności będą dla partii korzystniejsze — zdecydowało się zbojkotować wybory.

W wyniku nieobecności Węgierskiej Partii Socjaldemokratycznej walka wyborcza praktycznie została ograniczona do dwóch wielkich partii, co znalazło odzwierciedlenie również w wynikach. Wybory można było zorganizować na większości terytorium państwa wyznaczonego przez traktat zawarty w Trianon, wyjątek stanowiły tereny na wschód od Cisy, nadal okupowane przez wojska rumuńskie, oraz obszar Baranya, będący pod kontrolą wojsk serbskich. $Z$ tego względu można było zdecydować o losach 164 mandatów, z czego 34 okręgi były obcięte, ponieważ w mniejszym

${ }^{1}$ L. Hubai, Választók és választói jog Magyarországon 1920-1947, „Társadalmi Szemle” 1998, nr 7, s. 105-108; J. Gergely, Titkos választás és ellenforradalom - 1920, [w:] Parlamenti választások Magyarországon 1920-1998, red. G. Földes, L. Hubai, Budapest 1999, s. 50-55.

2 J. Gergely, Titkos választás és ellenforradalom..., s. 55-66. Magyarországi pártok politikai lexikona (1846-2010), red. I. Vida, Budapest 2011, s. 148-155. 
lub w większym stopniu były one pod obcą okupacją lub też zostały przyłączone do innego państwa. Wybory wywołały dość dużą mobilizację w społeczeństwie węgierskim, o czym świadczy liczba kandydatów (startowało 379 osób) oraz największa frekwencja w okresie międzywojennym (87-88\%). W tych warunkach politycznych nie było zaskoczeniem, że wybory parlamentarne przyniosły zwycięstwo dwóch największych ugrupowań: Partii Chrześcijańskiej Jedności Narodowej, która uzyskała 50 mandatów, oraz Niezależnej Partii Drobnych Posiadaczy Rolnych i Rolników — 75 mandatów. Uzyskały one odpowiednio $44,5 \%$ oraz $47,6 \%$ miejsc w parlamencie. Obok nich do parlamentu weszła Narodowa Partia Demokratyczna z sześcioma mandatami³.

\section{POCZĄTKOWA DZIALALNOŚĆ ZGROMADZENIA NARODOWEGO}

Nowo wybrany parlament 16 lutego 1920 r., po uroczystej mszy świętej, odprawionej w sali pod kopułą parlamentu, rozpoczął działalność na swoim pierwszym posiedzeniu. Początkowe działania w większości były oparte na porządku ukształtowanym podczas dualizmu, z taką różnicą, że wobec braku głowy państwa tę rolę w pewnym stopniu przejmował premier. Nic dziwnego, że kierownictwo parlamentu — przewodniczący, wiceprzewodniczący, szef kancelarii parlamentu oraz notariusze — zostali wyłonieni spośród polityków dwóch dużych partii. Na podstawie uzgodnień między szefami tych partii dokonano również podziału miejsc w komisjach parlamentarnych ${ }^{4}$. Wielu Węgrów w powstaniu parlamentu nie upatrywało jednak pozytywów i możliwości odrodzenia oraz symbolu państwowości. Wynikało to z faktu, że opinia publiczna musiała się zmierzyć z twardymi warunkami pokojowymi oraz z likwidacją państwa węgierskiego $\mathrm{w}$ jego historycznych granicach. Silniejsze stawało się przekonanie, że za przegraną wojnę i Trianon winę ponosi rewolucja 1918-1919. Wyniki wyborów odzwierciedlały również sprzeciw wobec rewolucji. Dla władzy ustawodawczej pilnym i ważnym zadaniem było wypracowanie podstaw funkcjonowania instytucji państwowych. Zgromadzenie Narodowe starało się spełnić te oczekiwania i w tym duchu uchwalono ustawę nr I z 1920 r., która później stała się ustawą zasadniczą. Ustawa została oparta na fundamentach kontrrewolucyjnych, unieważniła wszelkie działania Republiki Ludowej oraz Republiki Rad. Zagwarantowano w niej także funkcjonowanie ważniejszych organów władzy na podstawie regulacji sprzed $1918 \mathrm{r}$. Tak miało być aż do czasu przyjęcia zmian kolejnej reformy ${ }^{5}$. Z tego kontrrewolucyjnego myślenia w sposób logiczny powinno było wynikać całkowite przywrócenie ustroju państwa sprzed 31 października 1918 r., czyli sprzed tzw. rewolucji różanej. Jednak w Zgromadzeniu Narodowym były ostre spory wokół tego, w jakim stopniu można przywrócić stary porządek. Legitymiści optowali za jak najszerszym wdrożeniem starego porządku, podczas gdy obóz przeciwny — powołując się na bieżącą sytuację polityczną — całkowicie ten pomysł odrzucał. Ustawa nr I z 1920 r., choć pełna kompromisów, to jednak zasadniczo odcinała się od

${ }^{3}$ L. Hubai, Magyarország XX. századi választási atlasza, t. I, Budapest 2000, s. 21-25.

${ }^{4}$ L. Püski, A Horthy-korszak parlamentje, Budapest 2015, s. 54-59.

5 Magyar Törvénytár, 1920. Évi törvénycikkek, Budapest 1920, s. 6. 
następstwa prawnego, dając temu wyraz poprzez tworzenie jednoizbowego Zgromadzenia Narodowego w miejsce starego, dwuizbowego parlamentu. Większość posłów nie traktowała nowego organu jako stałej instytucji, czego wyrazem było używanie nazwy Zgromadzenie Narodowe oraz wyznaczenie okresu jego funkcjonowania na niezwykle krótki czas, tj. na dwa lata.

Dwie duże partie wygrywające wybory nie były jednolitymi strukturami politycznymi. Partia Chrześcijańskiej Jedności Narodowej składała się z różnych ugrupowań chrześcijańsko-socjalistycznych, konserwatywnych i skrajnie prawicowych. Z kolei w Partii Drobnych Rolników większość posłów należała do nurtu agrarno-demokratycznego oraz agrarno-konserwatywnego, jednak w jej skład wchodziły niewielkie ugrupowania skrajnie prawicowe. Oprócz nich mieszczańskie siły lewicowe były reprezentowane przez Narodową Partię Demokratyczną. Na podstawie wyników wyborów pojawiły się wątpliwości, czy któraś $\mathrm{z}$ dwóch dużych partii jest w stanie samodzielnie powołać rząd, dlatego też utworzyły ze sobą koalicję. $Z$ jednej strony konsekwencją tego posunięcia było powstanie rządu na czele z Sándorem Simonyi-Semadamem, mającego poparcie parlamentu, z drugiej zaś — stworzenie sytuacji wykluczającej powstanie opozycji zdolnej do utworzenia rządu.

Do spraw wymagających szybkiego uporządkowania należało wyjaśnienie praktycznego funkcjonowania organu ustawodawczego oraz jego kompetencji. Zgromadzenie Narodowe w gmachu parlamentu zajęło dotychczasową izbę poselską, co również w dziedzinie infrastruktury wiązało się z przejęciem dziedzictwa po wcześniejszym Zgromadzeniu Krajowym. W zakresie wewnętrznego funkcjonowania politycznego organ ustawodawczy przyjął tymczasowo regulamin z 1908 r., odrzucając bardziej restrykcyjny z 1913 r. ${ }^{6}$ Regulamin ten zapewnił szerokie pole manewru dla działań poselskich, m.in. nie ograniczał liczby i czasu wystąpień poselskich. Nieuniknione było również wyjaśnienie kompetencji głowy państwa. Ze względu na to, że obsadzenie królewskiego tronu natrafiło na przeszkody nie do przejścia, ponieważ zwycięskie państwa nie zgadzały się na powrót Karola IV lub też na zajęcie tronu przez inną osobą z dynastii Habsburgów, a wolni elektorzy wyboru króla nie byli w stanie wysunąć innego kandydata wyłonionego $\mathrm{w}$ ramach konsensu, zaistniała potrzeba rozwiązania doraźnego. W ten sposób zgodnie z ustawą nr I z 1920 r. jako rozwiązanie przejściowe powołano stanowisko regenta i określono jego kompetencje. Po przeprowadzeniu uzgodnień politycznych oraz przygotowaniach Zgromadzenie Narodowe 1 marca 1920 r. wybrało na regenta kraju Miklósa Horthyego, dotychczasowego głównodowodzącego armią. W taki sposób do marca $1920 \mathrm{r}$. powstały najważniejsze organa państwa węgierskiego (organ ustawodawczy, rząd, głowa państwa).

\section{UKLAD SIL PARTYJNO-POLITYCZNYCH}

Rząd Simonyi-Semadama miał ogromne poparcie większości parlamentarnej, jednak podział partyjno-polityczny posłów Zgromadzenia Narodowego pod wieloma

${ }^{6}$ Nemzetgyülési napló, 1920-1922, t. I, s. 16. 
względami wskazywał na brak stabilności. Przede wszystkim należało uzupełnić liczbę mandatów, dlatego też najpierw latem 1920 r. na wschód od Cisy, następnie jesienią 1921 r. w regionie Baranya przeprowadzono kolejne wybory do Zgromadzenia Narodowego, co było możliwe dzięki wycofaniu z tych terenów wojsk rumuńskich i serbskich. Do 164 posłów dołączyło 44, później kolejnych 11 posłów i na koniec 1921 r. izba osiągnęła pełną liczbę 219 posłów ${ }^{7}$. Na obu obszarach wybory wygrała Partia Drobnych Rolników, co nie tylko zwiększyło jej siłę, ale umożliwiało samodzielne rządzenie. Wewnętrzną spójność dwóch dużych partii osłabiał fakt, że były one zbudowane na współpracy różnych grup, do czego jeszcze dochodziła swoista cecha okresów zmian ustrojowych, polegająca na rozluźnieniu dyscypliny partyjnej. Dlatego nie było zaskoczeniem, że na początku $1922 \mathrm{r}$. blisko 1/3 posłów nie należała do tego samego ugrupowania, co bezpośrednio po wyborach. Jako symptom przemian obóz konserwatywny zaczął się szybko aktywizować i wiosną 1920 r. rozpoczął akcję na rzecz utworzenia nowej partii rządzącej. Ze względu na to, że ruch ten osiągnął jedynie ograniczone rezultaty, osoby, które przyłączyły się do niego, ostatecznie nie utworzyły własnej organizacji, a swoją politykę kontynuowały w „luźnym” ugrupowaniu pod nazwą zbiorczą „dysydenci”. W celu utworzenia stabilnej większości zdolnej do powołania nieformalnego rządu w połowie maja $1920 \mathrm{r}$. trzy ugrupowania stworzyły nową partię. Zjednoczona Chrześcijańsko-Narodowa Partia Drobnych Rolników i Rolników jednak funkcjonowała dalej jak rodzaj koalicji rządowej, której poszczególne frakcje zachowały swoją niezależność. Ostatecznie w lutym 1921 r. każde ugrupowanie odzyskało również formalnie swoją niezależnośćs ${ }^{8}$, co jednak nie zmieniło faktu, że polityka rządu opierała się na zmieniających się warunkach, wynikających z poparcia trzech partii walczących o swoich wyborców.

\section{DEMOKRATYZUJĄCY SIĘ ORGAN USTAWODAWCZY}

Skład społeczny pierwszej kadencji Zgromadzenia Narodowego przyniósł znaczące zmiany w stosunku do składu z początku stulecia. W wyniku demokratyzacji ordynacji wyborczej oraz zmiany struktury partyjnej nastąpiła radykalna wymiana elit. Przede wszystkim zaledwie $11 \%$ posłów zasiadało w ostatnim parlamencie okresu dualizmu. Politycy wchodzący do parlamentu w znacznej mierze reprezentowali nowe, młodsze pokolenie, dzięki czemu patrząc na cały okres Horthyego, to w 1920 r. zebrał się najmłodszy organ ustawodawczy pod względem średniej wieku (40,3 lat). Przed pierwszą wojną światową zawody reprezentowane w izbie były dość tradycyjne. Większość posłów (75\%) należała do trzech dużych grup społecznych: wielcy i średni właściciele ziemscy, urzędnicy i adwokaci. Struktura pierwszej kadencji Zgromadzenia Narodowego była bardziej zróżnicowana. Proporcja arystokratów spadła z $14,8 \%$ do $5,5 \%$, z kolei odsetek posłów pochodzenia chłopskiego wzrósł z $1,2 \%$ do $14,9 \%$. Jednocześnie zmalała liczba adwokatów - z 21,1\% do $11,2 \%$,

\footnotetext{
7 L. Hubai, Magyarország XX. századi választási atlasza..., s. 26-30.

${ }^{8}$ Magyarországi politikai pártok lexikona..., s. 155.
} 
a krąg zawodów inteligenckich znacząco się powiększył, przede wszystkim o osoby duchowne, nauczycieli, wykładowców akademickich ${ }^{9}$.

Instytucja ta zapewniała szerokie pole dla każdej działalności związanej z tradycyjną pracą poselską. Izba często obradowała i to nie jest przypadek, że w całym okresie rządów Horthyego, to w tej kadencji odbywano posiedzenia najczęściej (miesięcznie 13,1 posiedzeń). Posłowie - korzystając z możliwości, jakie zapewnił liberalny regulamin - mogli wyrazić swoje poglądy na temat projektów ustaw, pracy rządu oraz w zależności od osobistych ambicji mogli skorzystać z innych przywilejów poselskich. Na posiedzeniach często dochodziło do gwałtownych dyskusji czasami przeradzającymi się w osobiste starcia. Zgromadzenie Narodowe odpowiadało tradycyjnym oczekiwaniom stawianym nowoczesnym parlamentom, aby organ ustawodawczy stał się najważniejszym forum wyrażenia i zderzenia poglądów/opinii politycznych. Do tego jeszcze prace Zgromadzenia toczyły się pod kontrolą opinii publicznej. Co prawda cenzura z okresu wojny nadal obowiązywała, jednak prasa odgrywała ważną rolę w informowaniu o działalności parlamentu i mogła krytykować jego działania.

Ustawa nr I z 1920 r. stanowiła również o tym, że Zgromadzenie Narodowe było jedynym organem ustawodawczym, jednak jego pierwszeństwo w prawie publicznym nie podważało wcześniej ukształtowanej tradycji, według której inicjatorem i organem przygotowującym procesy legislacyjne był rząd ${ }^{10}$. Jednak to wcale nie oznaczało pozycji zależnej. Podczas pierwszej kadencji Zgromadzenia Narodowego najważniejsze warunki do utworzenia i utrzymania rządów stwarzała istniejąca większość parlamentarna, przez co organ ustawodawczy zapewniał legitymację dla rządu. Obowiązkiem nowego premiera było wygłoszenie exsposé w Zgromadzeniu Narodowym, co stanowiło okazję do wystąpień posłów. Do odpowiedzialności parlamentarnej dołączyło prawo organu ustawodawczego do kontroli. Posłowie — niezależnie od przynależności partyjnej — starali się wykorzystać każdą okazję, aby wyrazić swoją opinię i skrytykować działalność rządu. Charakterystycznym przykładem może być sytuacja, kiedy to w grudniu 1920 r. Pál Teleki kolejny raz otrzymał misję utworzenia rządu, to posłowie przez ponad dwa miesiące — od 17 grudnia 1920 r. do 26 lutego 1921 r. — debatowali nad exposé. Natomiast w dziedzinie finansów występowały pewne braki. Parlament węgierski tradycyjnie zajmował stanowisko, że rząd może prowadzić swoją działalność wyłącznie na podstawie budżetu przyjętego przez organ ustawodawczy. Jednak podczas pierwszej wojny światowej ta tradycyjna praktyka została zupełnie zarzucona, a rządy tworzyły swoje konstytucyjne zaplecze dla gospodarki finansowej na podstawie przejściowych upoważnień, które nie wymagały tej procedury. Co prawda, podczas pierwszej kadencji Zgromadzenia Narodowego istniała powszechna wola zlikwidowania stanu wyjątkowego, to jednak

${ }^{9}$ L. Püski, A Horthy-korszak parlamentje..., s. 23-24; I. Romsics, Bethlen István konzervativizmusa, [w:] Móra Ferenc Múzeum évkönyve, 1988/1, Szeged 1989, s. 325; D. Rudai, A politikai ideológia, pártszerkezet, hivatás és életkor szerepe a magyar pártok és a képviselőház életében, 1881-1935, Budapest 1936, s. 32-33; A. Schwarcz, A. Schönbaum, Paradox rendszerváltás: az 1910 és 1922 közötti parlamentek képviselői, [w:] Képviselök Magyarországon, t. I, red. G. Ilonszki, Budapest 2005, s. 113.

${ }^{10}$ M. Kozári, A dualista rendszer (1867-1918), Budapest 2005, s. 91. 
rzeczywiste wcielenie go w życie spowodowałoby wtedy, że zaistniałaby realna szansa zapewnienia równowagi w gospodarce państwa i zahamowanie procesów inflacyjnych. Chociaż poważne reformy Lóránta Hegedüsa, ministra finansów w rządzie Telekiego, miały właśnie to na celu, to jednak niepowodzenie tego eksperymentu doprowadziło do tego, że rządy swoją gospodarkę zabezpieczały nawet rozporządzeniami. $Z$ powyższych działań wynikało również to, że nie można było kontrolować polityki ekonomicznej rządów w sposób przyjęty, czyli w sprawozdaniach ${ }^{11}$.

Znanym faktem jest, że tron królewski pozostał pusty, co się wiązało z tym, że w systemie władzy zabrakło tego elementu, który wcześniej stanowił jeden z najważniejszych przeszkód do realizacji roli parlamentu. Z kolei Miklós Horthy, wybrany w marcu 1920 r. na regenta, odnośnie do Zgromadzenia Narodowego miał ograniczone kompetencje, również ograniczone były jego uprawnienia władzy. Większość parlamentarna wbrew pozorom wcale nie ułatwiała położenia szefów rządów. Już samo sformowanie rządu okazało się niełatwym zadaniem, ponieważ desygnowany premier musiał uwzględnić szereg różnorodnych interesów politycznych. Ze względu na to, że duże partie parlamentarne zwykle same miały problem $\mathrm{z}$ wysuwaniem propozycji personalnych, możliwych do zaakceptowania przez wszystkich, otworzyło to spore pole manewru dla Horthy'ego. Zgodnie z przepisami to regent powierzał utworzenie rządu, co z wyżej wymienionych powodów nie było wcale czystą formalnością. Wręcz przeciwnie, regent rzeczywiście mógł wpłynąć na powstanie poszczególnych rządów i na ich przetrwanie. W 1920 r. Pál Teleki, następnie w 1921 r. István Bethlen uzyskali fotel premiera przede wszystkim jako kandydaci regenta i mający jego poparcie ${ }^{12}$.

W taki sposób na początku 1920 r. rozpoczął się proces demokracji, znajdujący wyraz w umocnieniu i poszerzeniu funkcji parlamentarnych ${ }^{13}$. Jednocześnie ten proces nie był jednoznaczny i poza ustawodawstwem pojawiały się również sprzeczne tendencje. Okrucieństwa i ataki terrorystyczne przeprowadzane przez skrajne oddziały zbrojne i ugrupowania polityczne wskazywały na braki w porządku i bezpieczeństwie publicznym. Zgromadzenie Narodowe również przyczyniło się do ograniczenia swobód obywatelskich poprzez utrzymanie w mocy nadzwyczajnych dekretów na wypadek wojny, ponadto przyjęto reformy ograniczające prawa.

\section{DZIALALNOŚĆ USTAWODAWCZA PIERWSZEGO ZGROMADZENIA NARODOWEGO}

Parlamentarzyści przede wszystkim pragnęli się zajmować sprawami będącymi w zainteresowaniu opinii publicznej oraz wyborców, ponieważ w szerszym rozumieniu w każdej dziedzinie życia publicznego pojawiały się oznaki bałaganu i niepewności.

${ }^{11}$ L. Püski, Parlament és állami költségvetés Bethlen István miniszterelnöksége alatt, [w:] Megértö történelem, Tanulmányok a hatvanéves Gyarmati György tiszteletére, red. M. Baráth, G. Bánkuti, J.M. Rainer, Budapest 2011, s. 291-294.

12 I. Romsics, Bethlen István, Budapest 1991, s. 109-118.

${ }^{13}$ Z. Boros, D. Szabó, Parlamentarizmus Magyarországon (1867-1944). Parlament, pártok, választás, Budapest 2008, s. 309; I. Romsics, Múltról a mának, Budapest 2004, s. 227. 
Przyjęte rozwiązania nie raz wywołały jednak ostrą reakcję opinii publicznej. Reforma znana pod hasłem numerus clausus (ustawa XXV z 1920 r.) miała na celu ograniczyć nadprodukcję inteligencji poprzez ograniczenie liczby studentów przyjmowanych na wyższe uczelnie, która właśnie przez zmiany przeforsowane podczas debat w Zgromadzeniu Narodowym nabrały charakteru antysemickiego. Podobnie w 1920 r. doszło do ogłoszenia reformy rolnej (ustawa XXXVI z 1920 r.), która miała załagodzić napięcia w społeczności rolnej poprzez rozdawanie ziemi uprawnej ${ }^{14}$.

Przez ten dwuletni okres Zgromadzenie Narodowe musiało zmagać się z wieloma poważnymi wyzwaniami. Moim zdaniem to, że z częścią z nich nie umiało sobie poradzić, w głównej mierze nie było od niego zależne. Do takich spraw należy przede wszystkim zaliczyć kwestie związane z budżetem. Parlament na polu ustawodawstwa wykonał rzeczywiście ogrom pracy, gdyż podczas dwóch lat działalności omówiono i uchwalono 112 ustaw, wśród nich kilka o dużym znaczeniu. Jednocześnie w dziedzinie prawa konstytucyjnego za brak lub zaniechanie reform — wraz z rządami Telekiego i Bethlena - ciążyła na parlamencie duża odpowiedzialność. To przede wszystkim duże partie, kultywujące ideologię kontrrewolucji, upierały się przy tym, aby Węgry w sposób niezmienny posiadały tzw. konstytucję historyczną, odrzucając projekty stworzenia nowej konstytucji. Funkcjonowanie poszczególnych gałęzi władzy państwa nadal opierało się na ustawach przyjętych w okresie dualizmu na podstawie ukształtowanej wówczas praktyki. Oczywiście uczestnicy życia politycznego w mniejszym lub większym stopniu mieli świadomość tego, że historyczne regulacje są po części przestarzałe, mają braki, lecz w wielu dziedzinach nie następowały poważniejsze zmiany. Wśród spraw o mniejszym znaczeniu można wspomnieć o tym, że nie uregulowano dokładnie, w jakich warunkach może minister albo cały rząd stracić poparcie większości parlamentu. Poważniejsza sprawą było to, że parlament jeszcze w 1920 r. powołał komisję do wypracowania nowego regulaminu parlamentu, która do sierpnia przygotowała swój raport ${ }^{15}$, nad którym jednak nigdy nie debatowano. Większość członków Zgromadzenia Narodowego miała świadomość, że samorządy miejskie i te na prowincji nie odpowiadają wymogom nowoczesności. W październiku 1920 r. Gyula Ferdinandy, minister sprawiedliwości w rządzie Pála Teleki, przedstawił swoje pomysły w tej sprawie, które jednak kilka miesięcy później — wraz z jego upadkiem - przepadły ${ }^{16}$. W ustawie I z 1920 r. ustanowiono, że Zgromadzenie Narodowe jest wyłącznym przedstawicielem narodowej suwerenności. $Z$ takiego stanowiska wyraźnie wynikało odrzucenie roszczeń starego układu arystokracji wobec władzy. Jednak to nie oznaczało jeszcze jednostronnego poparcia dla parlamentu jednoizbowego. Rząd Bethlena przygotował konkretną propozycję utworzenia wyższej izby, po części opartej na tradycjach, a po części na nowych założeniach. Swoją propozycję reformy przedłożył Zgromadzeniu Narodowemu w lipcu 1921 r. Właściwe komisje zgodnie ze swoim trybem projekty zaopiniowały,

14 M.M. Kovács, Törvénytöl sújtva - a numerus clausus Magyarországon, 1920-1945, Budapest 2012; J. Nagy, A Nagyatádi-féle földreform. 1920-1928, Nyíregyháza 1993.

15 Nemzetgyülési Irományok, 1920-1922..., t. IV, s. 1-111.

16 J. Ruszoly, Alkotmányjogi reformtörekvések az első nemzetgyülés idején, Szeged 1974, s. 14-17. 
ale już nie doszło do ich omówienia na posiedzeniu plenarnym ${ }^{17}$. Podobnie nie było żadnych postępów w dziedzinie uregulowania ordynacji wyborczej, co w późniejszym czasie pociągnęło za sobą poważne skutki.

Z tym zjawiskiem po części wiązał się fakt, że układ sił partyjnych ukształtowany po wyborach w 1920 r. nie był oparty na solidnych fundamentach. Dwa duże ugrupowania tylko w mocno ograniczonym stopniu były w stanie zmusić swoich członków do dyscypliny partyjnej podczas głosowania. Znacząca część posłów wykonywała swoją pracę w komisjach co najmniej w sposób niedbały, ale na plenarnych posiedzeniach zapewniających popularność wykazała aktywność. Jednak ta aktywność często kończyła się na bezcelowych dyskusjach. Można uznać za uzasadnione słowa krytyczne Istvána Bethlena, wypowiedziane z perspektywy lat, tj. w 1931 r.: „Miejsce Zgromadzenia Narodowego zajęło jednoizbowe Zgromadzenie Narodowe, w którym więcej było [...] nadużyć władzy niż praktyki politycznej i politycznego wykształcenia. W tym Zgromadzeniu jeszcze dominowały nastroje rewolucyjne i kontrrewolucyjne, a czas poświęcony na debaty w większości wypełniały osobiste rozgrywki i często dochodziło do rękoczynów, zamiast rozwiązywać wielkie, życiowe problemy kraju"18. Przykładowo w styczniu 1922 r. przewodniczący parlamentu Gaszton Gaál, co prawda nie w trakcie pełnienia swoich obowiązków służbowych, ale na jednym z posiedzeń wdał się w ostrą wymianę zdań z Ödönem Beniczkym, jednym z polityków legitymistów. W trakcie kłótni ten ostatni wyjął broń, na co Gaál go uderzył. Po tym zajściu Gaszton Gaál złożył dymisję, lecz większość posłów ponownie wybrała go na to stanowisko ${ }^{19}$.

\section{ALTERNATYWY POLITYCZNE}

István Bethlen jako premier przy słabości prac parlamentarnych również odegrał znaczącą rolę. Kiedy w kwietniu 1921 r. został szefem rządu, doskonale wiedział, że jego konserwatywne plany reformatorskie trafią na opór polityków demokratycznych, chrześcijańsko-socjalistycznych i skrajnie prawicowych, stanowiących większość Zgromadzenia Narodowego. Z tego względu Bethlen dążył do całkowitego przekształcenia istniejącej struktury partyjnej i utworzenia dużej konserwatywnej partii rządzącej, posiadającej stabilną większość ${ }^{20}$. Po długich przygotowaniach i zagrywkach taktycznych na początku 1922 r. Bethlen wraz z swoimi zwolennikami wstąpił do Niezależnej Partii Drobnych Rolników. Dla sformalizowania ugrupowania przyjęto nazwę - Partia Chrześcijańsko-Chrześcijańscy Drobni Rolnicy-Mieszczanie, lecz w życiu publicznym rozpowszechniła się krótsza i bardziej wymowna nazwa - Partia Jedności ${ }^{21}$. W wyniku tych zmian grupa dysydentów przestała istnieć,

${ }^{17}$ Nemzetgyülési Irományok, 1920-1922.., t. XI, s. 227-261; J. Ruszoly, Alkotmányjogi reformtörekvések..., s. 39.

${ }_{18}$ Bethlen István gróf beszédei és írásai, t. II, Budapest 1933, s. 321.

19 A magyar országgyülés története 1867-1926, red. A. Balla, t. II, Budapest 1927, s. 459.

${ }^{20}$ I. Romsics, Bethlen István..., s. 141-143.

${ }^{21}$ R. Barta, Az Egységes Párt létrejötte, [w:] Emlékkönyv Gunst Péter 70. születésnapjára, red. J. Barta, L. Pallai, Budapest 2004, s. 332-334. 
a Partia Jedności w Zgromadzeniu Narodowym również samodzielnie dysponowała większością zdolną do utworzenia rządu. Pozycję Bethlena dodatkowo wzmocnił spektakularny proces rozpadu strony chrześcijańskiej ${ }^{22}$. Premier miał jednak świadomość, że jego szybko zmontowana większość stoi na ,glinianych nogach”, przecież również wewnątrz partii rządzącej znaczne grupy stoją daleko od jego polityki. Dla premiera jedyną drogą była zmiana ordynacji wyborczej i przy pomocy nowych wyborów parlamentarnych przeformowanie składu osobowo-politycznego swojej partii. Jednak stworzenie ordynacji wyborczej teoretycznie należało do kompetencji organu ustawodawczego. $\mathrm{Z}$ tego powodu Bethlen do ostatniej chwili zwlekał ze złożeniem odnośnego projektu ustawy, wiedząc, że większość izby nie zagłosowałaby za dążeniami reformatorskimi zawężającymi prawa. Kiedy jednak doszło do złożenia w parlamencie propozycji ordynacji wyborczej, Zgromadzenie Narodowe już nie zdążyło projektu omówić w ramach swojego ustawowego czasu funkcjonowania i podjąć w tej sprawie decyzji. Szef rządu zdecydował, że w tej sytuacji nie będzie eksperymentował z przedłużeniem okresu działalności Zgromadzenia Narodowego. Dlatego 16 lutego premier — powołując się na upływ ustawowego czasu - zamknął posiedzenie. Z kolei bez przyjętej ustawy o prawach wyborczych Bethlen wdrożył w życie swój wcześniejszy projekt ustawy w formie rozporządzenia. To wszystko oznaczało, że pierwsze Zgromadzenie Narodowe było w stanie uzyskać jedynie ograniczone wyniki na polu konsolidacji politycznej, a uzupełnienie tego procesu pozostawiono na następną kadencję, podczas której pomysły i zamiary premiera odgrywały decydującą rolę.

\section{BIBLIOGRAFIA}

ŹRÓDŁA

Az 1920. február 16-ára hirdetett nemzetgyülés naplója, t. I-XVII.

Az 1920. február 16-ra hirdetett nemzetgyülés irományai, t. I-XIII.

Bethlen István gróf beszédei és írásai, t. II, Budapest 1933.

Hubai L., Magyarország XX. századi választási atlasza, t. I, Budapest 2000.

Magyar Törvénytár, 1920. évi törvénycikkek, Budapest 1920.

A magyar országgyülés története 1867-1926, red. A. Balla, t. II, Budapest 1927.

\section{PIŚMIENNICTWO}

Barta R., Az Egységes Párt létrejötte, [w:] Emlékkönyv Gunst Péter 70. születésnapjára, red. J. Barta, L. Pallai, Budapest 2004.

Boros Z., Szabó D., Parlamentarizmus Magyarországon (1867-1944). Parlament, pártok, választás, Budapest 2008.

Gergely J., A keresztényszocializmus Magyarországon 1903-1923, Budapest 1977.

Gergely J., Titkos választás és ellenforradalom - 1920, [w:] Parlamenti választások Magyarországon 1920-1998, red. G. Földes, L. Hubai, Budapest 1999.

Hubai L., Választók és választói jog Magyarországon 1920-1947, „Társadalmi Szemle” 1998, nr 7.

22 J. Gergely, A keresztényszocializmus Magyarországon 1903-1923, Budapest 1977, s. 163-167. 
Kovács M.M., Törvénytöl sújtva - a numerus clausus Magyarországon, 1920-1945, Budapest 2012.

Kozári M., A dualista rendszer (1867-1918), Budapest 2005.

Magyarországi pártok politikai lexikona (1846-2010), red. I. Vida, Budapest 2011.

Nagy J., A Nagyatádi-féle földreform. 1920-1928, Nyíregyháza 1993.

Püski L., A Horthy-korszak parlamentje, Budapest 2015.

Püski L., Parlament és állami költségvetés Bethlen István miniszterelnöksége alatt, [w:] Megértő történelem, Tanulmányok a hatvanéves Gyarmati György tiszteletére, red. M. Baráth, G. Bánkuti, J.M. Rainer, Budapest 2011.

Romsics I., Bethlen István konzervativizmusa, [w:] Móra Ferenc Múzeum évkönyve, 1988/1, Szeged 1989.

Romsics I., Bethlen István, Budapest 1991.

Romsics I., Múltról a mának, Budapest 2004.

Rudai D., A politikai ideológia, pártszerkezet, hivatás és életkor szerepe a magyar pártok és a képviselöház életében, 1881-1935, Budapest 1936.

Ruszoly J., Alkotmányjogi reformtörekvések az első nemzetgyülés idején, Szeged 1974.

Schwarcz A., Schönbaum A., Paradox rendszerváltás: az 1910 és 1922 közötti parlamentek képviselöi, [w:] Képviselök Magyarországon, t. I, red. G. Ilonszki, Budapest 2005. 